DOI: $10.14720 /$ aas.2016.107.2.08

Agrovoc descriptors: Cyperus esculentus, tubers, production technology, plant developmental stages, soaking, sprouting

Agris category code: F01

\title{
Effects of tuber size, soaking hours and sprouting media on sprouting of tiger nut (Cyperus esculentus L. var. sativa) tubers
}

\author{
Thomas Oladeji FABUNMI ${ }^{1 *}$, Sunday Ojo ADIGBO ${ }^{2}$, Joy Nwakaego ODEDINA ${ }^{1}$ and Yanmife Iyanu \\ AKINSANYA $^{1}$
}

Received February 17, 2016; accepted May 03, 2016.

Delo je prispelo 17. februarja 2016, sprejeto 03. maja 2016.

\begin{abstract}
Tiger nut, Cyperus esculentus L., is one of the underutilized and neglected food crops in most parts of the world leading to limited information on its production technology. A trial arranged in a $3 \times 4 \times 2$ factorial of a completely randomized design was conducted in a green house of the Federal University of Agriculture, Abeokuta, Nigeria, to evaluate the effects of tuber size (large, medium and small), soaking duration $(0,24,48$ and 72 hours) and sprouting media (cotton wool and polythene bag) on the sprouting of tiger nut. Significant interactions were observed between growth media and soaking hours as well as between tuber sizes and soaking hours on the sprouting of tiger nut. Soaking beyond 24 hours before placement in sprouting medium led to a significant reduction in number of sprouted tubers in polythene bags. Small sized tubers had reduced $(p<0.05)$ number of sprouts when soaked beyond 24 hours. Sprouting of tiger nut was better using medium size tubers soaked for 24 hours and placed between layers of cotton wool.
\end{abstract}

Key words: soaking hours, sprouting media, tiger nut, tuber sizes

\section{IZVLEČEK}

UČINEK VELIKOSTI GOMOLJEV, UR NAMAKANJA

IN NAKALITVENEGA MEDIJA NA NAKALITEV

GOMOLJEV UŽITNE OSTRICE (Cyperus esculentus L. var. sativa)

Užitna ostrica (Cyperus esculentus) je ena izmed premalo uporabljenih in spregledanih vrtnin v večjem delu sveta zaradi pomanjkanja informacij o tehnologiji njene pridelave. $\mathrm{V}$ ta namem je bil v rastlinjaku Federal University of Agriculture, Abeokuta, Nigeria izveden naključni $3 \times 4 \times 2$ faktorski poskus za ovrednotenje učinkov velikosti gomoljev (veliki, srednji in drobni), časa namakanja $(0,24,48$ in 72 ur) in nakalitvenega medija (bombažna volna in polietilenske vrečke) na nakalitev užitne ostrice. Značilni medsebojni učinki so bili opaženi med rastnim medijem in časom namakanja in velikostjo gomoljev. Namakanje več kot 24 ur pred namestitvijo gomoljev v nakalitveni medij je vodilo $\mathrm{k}$ značilnemu zmanjšanju nakalitve v polietilenskih vrečkah. Majhni gomolji so imeli manjše $(p<0.05)$ število poganjkov, če so bili prej namakani več kot 24 ur. Nakalitev gomoljev užitne ostrice je bila boljša, če so bili uporabljeni srednje veliki gomolji, namakani 24 ur in položeni med plasti bombažne volne.

Ključne besede: ure namakanja, nakalitveni medij, užitna ostrica, velikost gomoljev

\section{INTRODUCTION}

Tiger nut, Cyperus esculentus is one of the underutilized food crops grown in many parts of the world, with little climatic challenges. It is still considered a mere weed in many quarters: for example it was one of the plants listed as weeds with some food value in Africa (Hillocks, 1998). More recently, this crop has also been recognized as one of the 32 uncultivated plants with agricultural potentials in Nigeria (NACGRAB, 2008). Tiger nut though not usually cultivated in

\footnotetext{
Department of Plant Physiology and Crop Production, Federal University of Agriculture, Abeokuta; * corresponding author: tomdeji@yahoo.com

Institute of Food Security, Environmental Resources and Agricultural Research, Federal University of Agriculture, Abeokuta
} 
the southwestern part of Nigeria, it is not only consumed but it is a source of income to certain groups of people. Tiger nut is sold commercially as either fresh tubers (achieved after hours of soaking) or dried tubers especially by the Hausas who are seen displaying tiger nut and selling a kilogram of its fresh tubers for about $\$ 1$.

According to Sanchez-Zapata et al. (2012), tiger nut has attracted very little scientific and technological attention. This is in spite of its numerous food, health and economic benefits. Tiger nut is popular in Spain where it is grown primarily for the production of "horchata de chufa" (wikipedia encyclopedia), it contains appreciable amount of essential elements like $\mathrm{Na}, \mathrm{K}, \mathrm{Mg}, \mathrm{Mn}$, $\mathrm{Ca}, \mathrm{Fe}$ and $\mathrm{Zn}$ (Imam et al., 2013), it is also rich in dietary fiber, vitamins $\mathrm{C}$ and $\mathrm{E}$, used in control of diabetes and blood pressure (www.tigernuts.com, Bamishaiye and Bamishaiye, 2011, www.naij.com, empowered sustenance.com, www.naij.com,).

Exploiting the potentials of such underutilized food crops will become more and more cardinal to achieving food security especially in the developing countries and ensuring ecological stability in the face of ever increasing human population and climate change.

Constraints identified to be restricting the production of tiger nut include the label of the crop as a mere weed by many developed countries, difficulties of harvesting the tubers, problems of pest like red ants, termites and rodents. Another important constraint is erratic field establishment due to lack of uniformity in tuber sizes and differential rate of sprouting when planted directly. Adequate stand establishment cannot be compromised in crop production as labor, time, solar radiation and other inputs will be wasted if the field is scanty. Efforts directed at ensuring uniform field include soaking of tubers intended for planting and sprouting the tubers in baskets, while picking sprouted tubers at intervals for field establishment. Teiteh and Ofori (1998) reported that in Ghana, the common practice among local growers of tiger nut is to soak the tubers in water for 3 to 4 days to facilitate germination while changing the water every day to prevent rot; and that the soaked nuts may be planted direct, or kept in a basket until they begin to sprout between 7 and 12 days after soaking. Sprouted nuts are picked every day and planted.

Repeated picking of sprouted tubers for field establishment will be cumbersome and boring as a single operation will be carried out several times before completion. Furthermore, since agriculture is time bound, loss of time could later lead to exposure of crops to shortage of growth resources especially water in rain-fed agriculture. Since the tubers also vary in size, the establishment of an appropriate soaking period for a range of tuber size is important. Preparation of an appropriate growth medium that could produce more synchronized sprouting can be very helpful for the production of tiger nut.

The aim of the study was to evaluate the sprouting of tiger nut as affected by tuber sizes, soaking hours and different growth media. The objectives of the trials are:

1. To evaluate the effect of soaking duration on the sprouting.

2. To determine appropriate soaking duration for different tuber sizes.

3. To evaluate the effect of sprouting media on the rate of sprouting of tiger nut.

\section{MATERIALS AND METHODS}

The trial was carried out in a screen house of the College of Plant Science and Crop Production of the Federal University of Agriculture, Abeokuta, between January and February 2015.

Dried tiger nut tubers used for both trials were sorted into small, medium and large by visual observation and then weighed. The average tuber weights based on 240 tubers were $0.14 \mathrm{~g}, 0.31 \mathrm{~g}$ and $0.52 \mathrm{~g}$, for small, medium and large tubers respectively. The sorted tubers were soaked in water for $0,24,48$ and 72 hours.

The soaking treatment commenced with the tubers that were soaked for 72 hours, then those soaked for 48 hours and finally those soaked for 24 hours, 
in order to conclude all treatments at the same time.

This trial was a $3 \times 4 \times 2$ factorial based on a completely randomized design involving three replicates. There were three tiger nut tuber sizes large, medium and small, as specified above, soaked in water at a room temperature for either 0 , 24,48 or 72 hours and sprouted in either polythene bag or cotton wool.

After the soaking treatments, twenty tubers each of small, medium and large tuber sizes which had been soaked for 24,48 , or 72 hours were then placed between two layers of cotton wool or black polythene in Petri dishes for the sprouting trial, and the control ( 0 hour or no soaking) was used in the analysis as the standard. The standard planted in the soil to represent direct planting. Both the cotton wool and polythene bag were sprinkled with water to prevent desiccation. The polythene bag was then loosely tied while for the cotton wool, its top layer was used to cover the tubers before water was sprinkled on them.

\subsection{Data collection}

The data collected involved cumulative number of sprouted tubers on daily basis from the $3^{\text {rd }}$ to the $14^{\text {th }}$ day after being kept in sprouting media. Temperatures of the growth media were also recorded. The collected data were subjected to analysis of variance (ANOVA), while means that were significantly different were separated using the least significant difference (LSD) at $5 \%$ probability level using GENSTAT statistical package.

\section{RESULTS AND DISCUSSION}

\subsection{Effects of tuber sizes, soaking hours and growth media on sprouting of tiger nuts}

Table 1 presents the effect of tuber sizes, soaking hours and growth media on sprouting of tiger nuts. Sprouting was not significantly affected by both tuber sizes and soaking hours except on the $4^{\text {th }}$ day after placement on growth media when the control (no priming) was characterized by a significantly lower number of sprouted tubers relative to other treatments.

The growth media significantly affected the sprouting. The tubers enclosed in cotton wool sprouted significantly faster than those in polythene bags $(P<0.05)$ from the $3^{\text {rd }}$ to the $14^{\text {th }}$ day of observation. The interaction between the soaking hours and growth media on the sprouting of tiger nut was also significant from the fourth to fourteenth day after placement in the growth media.
Better sprouting in cotton wool when compared to the polythene bag, in this study, could be due to better aeration. Oxygen is needed for germination and might be limited in polythene bags, even though polythene bag could better conserve moisture and have higher temperature which are also factors required for germination. The superiority of these two factors in polythene bag did not lead to a faster rate of sprouting. The oxygen level has been shown to be an important environmental factor in seed germination, Data from germination of cauliflower (Brassica oleracea L. var. botrytis) showed that reducing $\mathrm{O}_{2}$ percentage to $10 \%$ slightly delayed germination, but further reductions to 5 or $3 \%$ both delayed and reduced the final germination percentage (Power and Fonteyn, 1995). Similarly, the major impact of oxygen supply in seed germination can be seen in the fact that once germination begins with seed imbibitions, dry seeds resume metabolic activities including respiration (Bradford et al., 2007). 
Table 1: Effects of tuber sizes, soaking hours and growth media on sprouting of tiger nut tubers

\begin{tabular}{|c|c|c|c|c|c|c|c|c|c|c|c|c|}
\hline \multirow[b]{2}{*}{ Treatment } & \multicolumn{11}{|c|}{ Cumulative number of sprouted tubers on different days after planting } & \multirow[b]{2}{*}{$14^{\text {th }}$} \\
\hline & $3^{\text {rd }}$ & $4^{\text {th }}$ & $5^{\text {th }}$ & $6^{\text {th }}$ & $7^{\text {th }}$ & $8^{\text {th }}$ & $9^{\text {th }}$ & $10^{\text {th }}$ & $11^{\text {th }}$ & $12^{\text {th }}$ & $13^{\text {th }}$ & \\
\hline \multicolumn{13}{|l|}{ Tuber Size } \\
\hline Small & 3.4 & 5.8 & 7.9 & 9.3 & 9.6 & 10.5 & 11.2 & 11.7 & 12.5 & 12.9 & 13.3 & 13.6 \\
\hline Medium & 6.0 & 7.3 & 9.2 & 11.0 & 11.7 & 13.4 & 13.7 & 14.0 & 14.7 & 15.1 & 15.3 & 15.3 \\
\hline Large & 6.5 & 8.9 & 11.0 & 12.3 & 12.6 & 13.4 & 13.6 & 13.8 & 14.1 & 14.8 & 14.8 & 14.8 \\
\hline LSD & ns & ns & ns & ns & ns & ns & ns & ns & ns & ns & ns & ns \\
\hline \multicolumn{13}{|l|}{$\begin{array}{l}\text { Soaking } \\
\text { hours }\end{array}$} \\
\hline 0 & 3.0 & 2.8 & 7.9 & 10.8 & 11.8 & 13.0 & 13.4 & 13.4 & 13.7 & 14.9 & 15.2 & 15.2 \\
\hline 24 & 5.5 & 9.3 & 10.8 & 11.6 & 12.3 & 14.1 & 14.9 & 15.5 & 16.3 & 16.6 & 16.8 & 16.8 \\
\hline 48 & 7.2 & 8.8 & 9.5 & 10.8 & 10.8 & 11.8 & 12.1 & 12.6 & 13.3 & 13.6 & 13.6 & 13.6 \\
\hline 72 & 5.4 & 8.4 & 9.3 & 10.3 & 10.4 & 10.7 & 10.7 & 11.1 & 11.6 & 12.1 & 12.2 & 12.7 \\
\hline LSD & $\mathrm{ns}$ & 2.72 & ns & ns & ns & ns & ns & ns & ns & ns & ns & ns \\
\hline \multicolumn{13}{|l|}{ Growth } \\
\hline \multicolumn{13}{|l|}{ Media } \\
\hline Cotton Wool & 7.2 & 9.9 & 12.1 & 14.6 & 15.3 & 16.3 & 16.6 & 16.8 & 16.9 & 17.3 & 17.4 & 17.4 \\
\hline Poly Bag & 3.4 & 4.8 & 6.7 & 7.1 & 7.3 & 8.5 & 9.0 & 9.5 & 10.6 & 11.3 & 11.5 & 11.8 \\
\hline LSD & 1.64 & 1.92 & 1.74 & 1.73 & 0.84 & 1.76 & 1.79 & 1.82 & 1.85 & 1.85 & 1.84 & 1.84 \\
\hline $\mathrm{TS} \times \mathrm{SH}$ & 4.01 & $\mathrm{~ns}$ & ns & ns & ns & ns & ns & ns & ns & $\mathrm{ns}$ & ns & ns \\
\hline $\mathbf{T S} \times \mathbf{G M}$ & $\mathrm{ns}$ & ns & ns & ns & $\mathrm{ns}$ & ns & ns & ns & ns & ns & ns & ns \\
\hline $\mathbf{G M} \times \mathbf{S H}$ & ns & 3.84 & 3.48 & 3.46 & 1.68 & 3.52 & 3.58 & 3.64 & 3.70 & 3.71 & 3.67 & 3.68 \\
\hline $\mathbf{T S} \times \mathbf{S H} \times \mathbf{G M}$ & ns & ns & ns & ns & ns & ns & ns & ns & ns & ns & ns & ns \\
\hline
\end{tabular}

TS - Tuber Sizes SH - Soaking Hours $\quad$ GM - Growth Media ns = not significant

\subsection{Interaction of growth media and soaking hours on sprouting of tiger nut tubers}

The interactions of growth media and soaking hours on the sprouting of tiger nut from the $4^{\text {th }}$ to 14DAP (days after planting) is presented in Figures 1-11. A similar pattern was observed across all the days of observations; sprouting in cotton wool was best achieved by soaking the tubers for 48 hours. On the other hand apart from the observation made on the fourth day after placement, sprouting of tiger nut in the polythene bags declined as the duration of soaking increased beyond 24 hours, this cut across the $5^{\text {th }}$ to the $14^{\text {th }}$ day after placement in the polythene bag. 


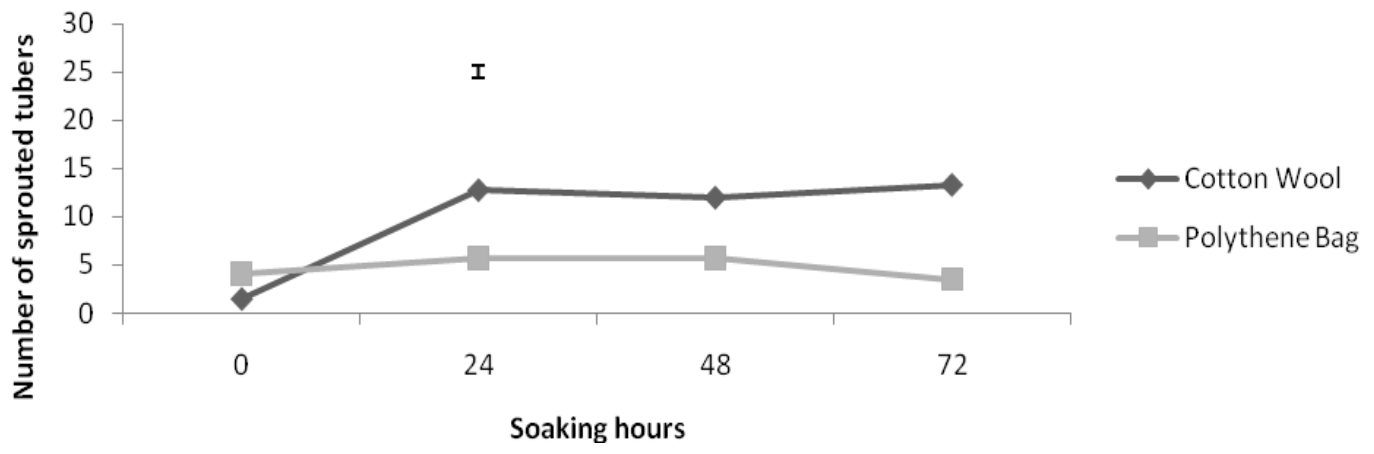

Figure 1: Interaction of growth media and soaking hours on sprouting of tiger nut tubers at 4DAP

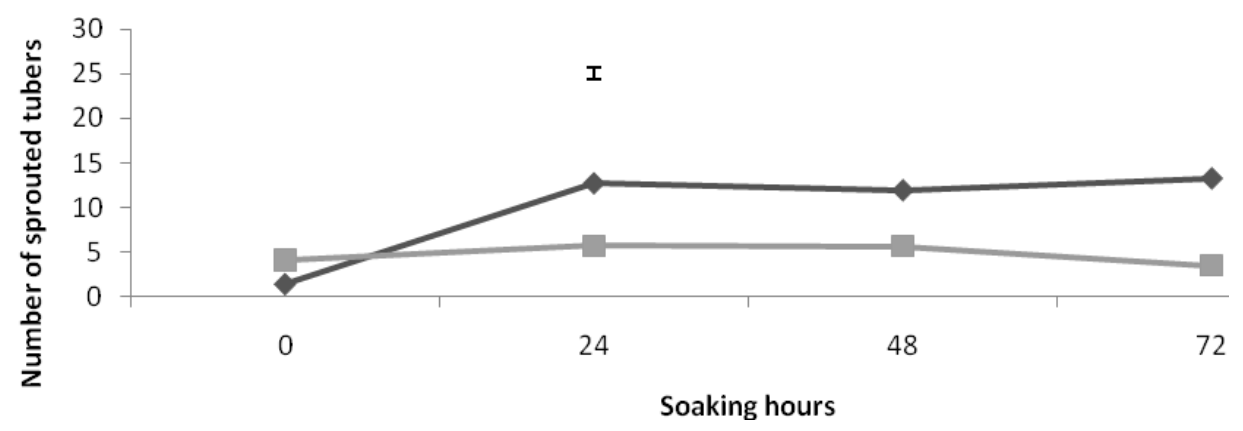

Figure 2: Interaction of growth media and soaking hours on sprouting of tiger nut tubers at 5DAP

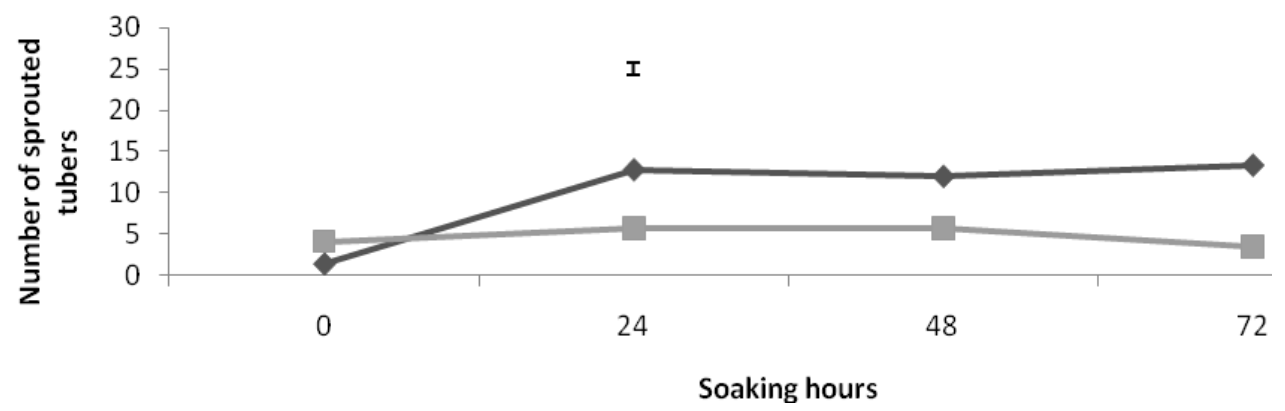

Figure 3: Interaction of growth media and soaking hours on sprouting of tiger nut tubers at 6DAP

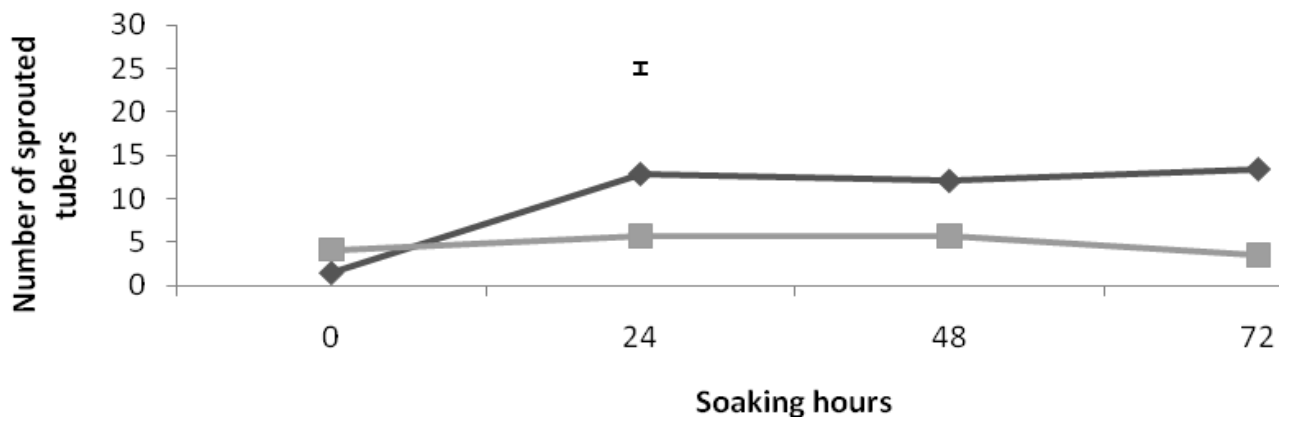

Figure 4: Interaction of growth media and soaking hours on sprouting of tiger nut tubers at 7DAP 


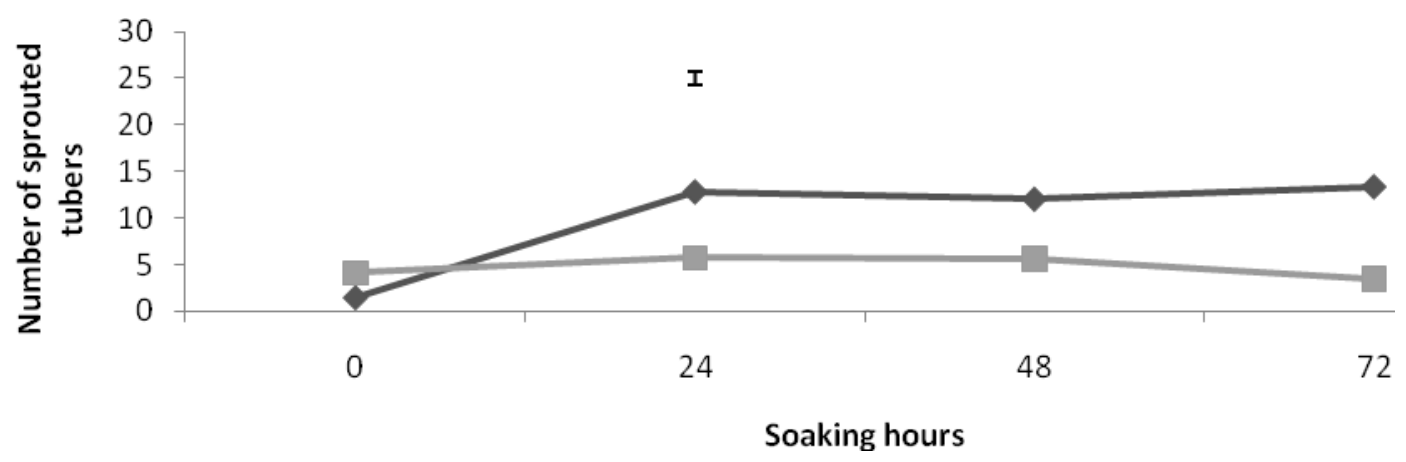

Figure 5: Interaction of growth media and soaking hours on sprouting of tiger nut tubers at 8DAP

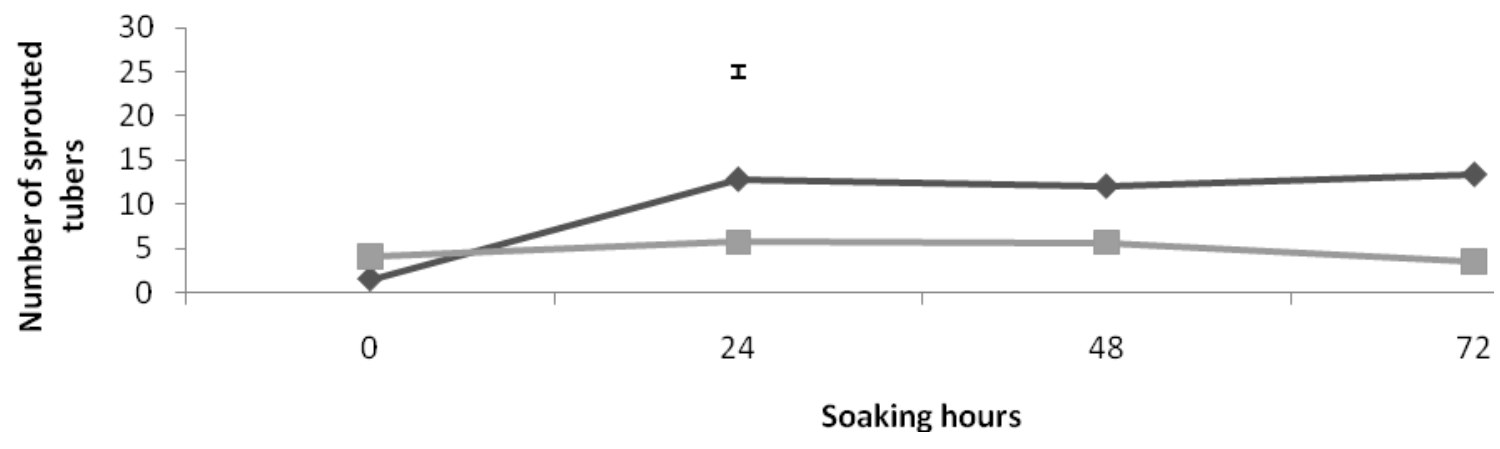

Figure 6: Interaction of growth media and soaking hours on sprouting of tiger nut tubers at 9DAP

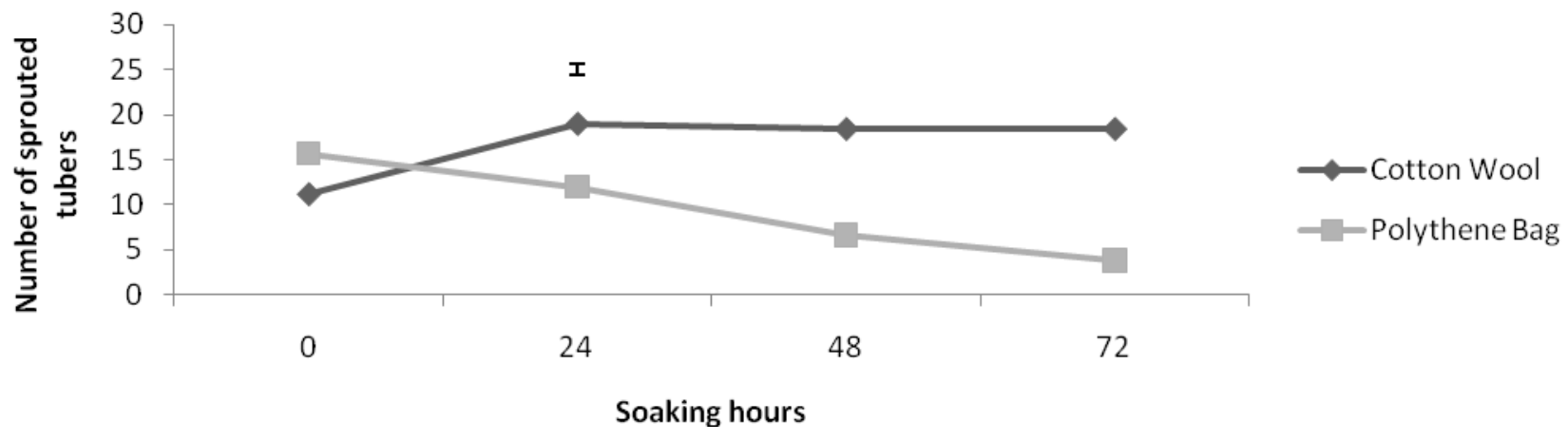

Figure 7: Interaction of growth media and soaking hours on sprouting of tiger nut tubers at 10DAP

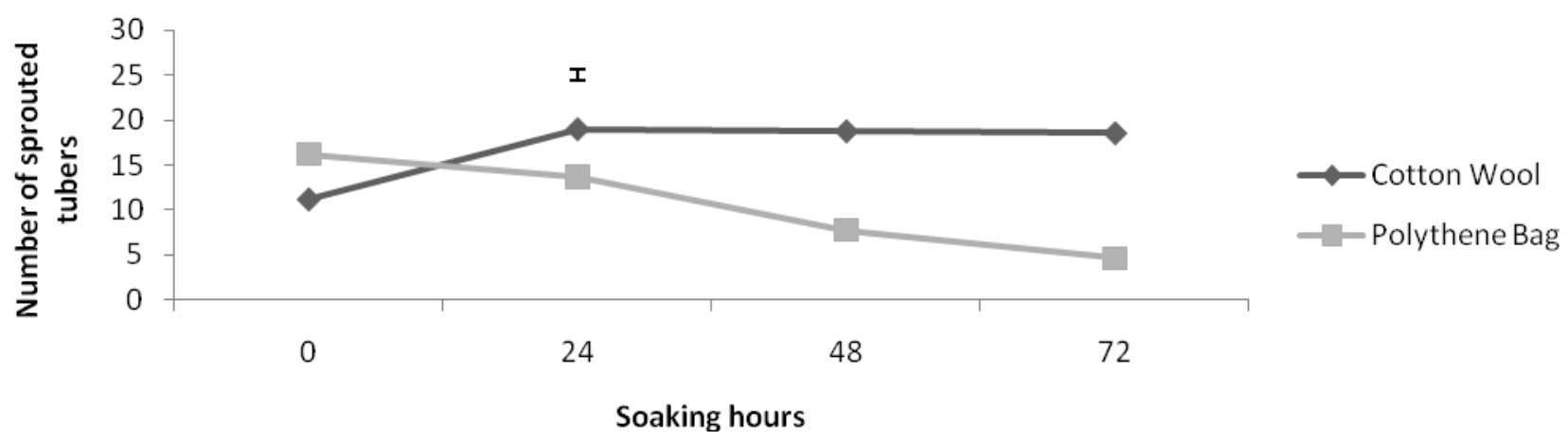

Figure 8: Interaction of growth media and soaking hours on sprouting of tiger nut tubers at 11DAP 


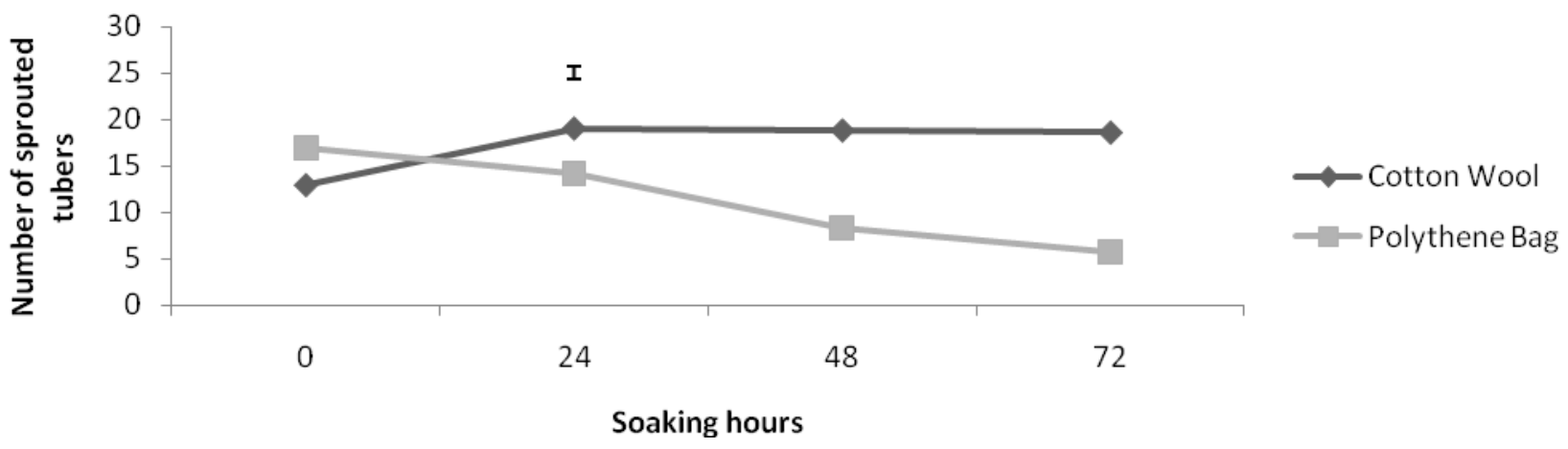

Figure 9: Interaction of growth media and soaking hours on sprouting of tiger nut tubers at 12DAP

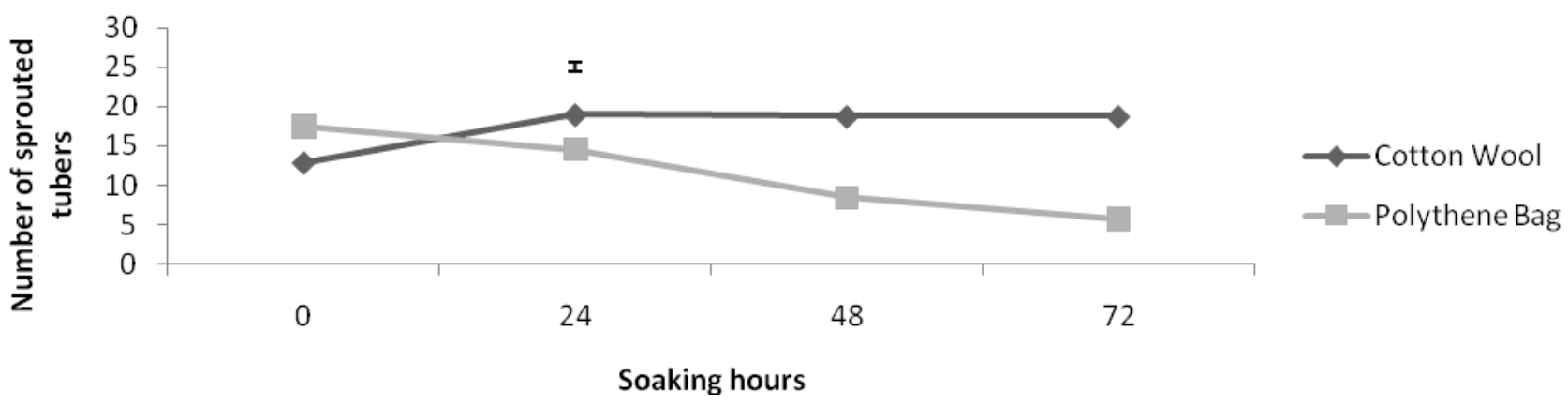

Figure 10: Interaction of growth media and soaking hours on sprouting of tiger nut tubers at 13DAP

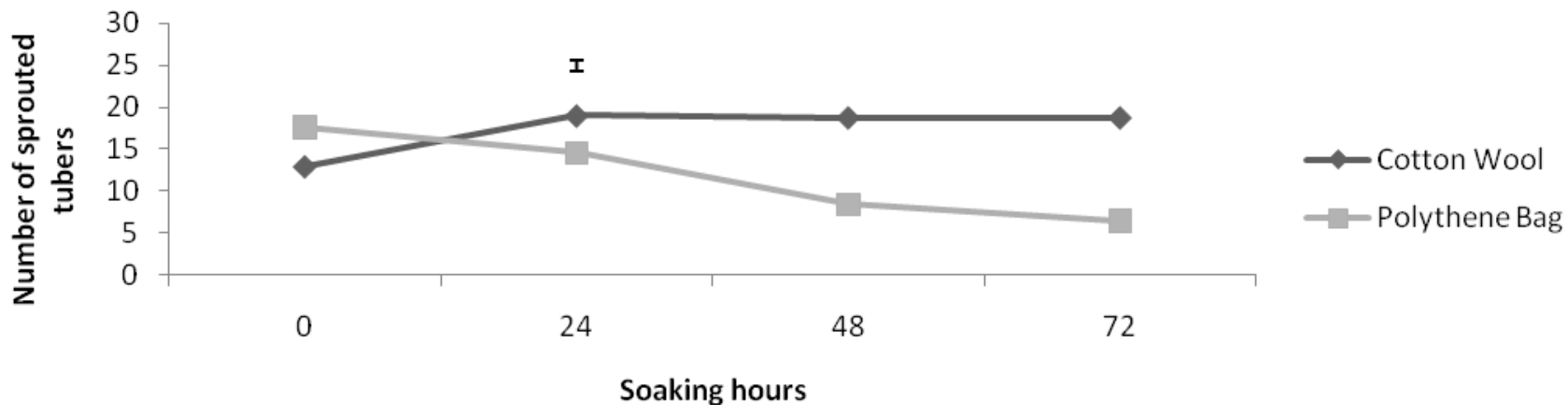

Figure 11: Interaction of growth media and soaking hours on sprouting of tiger nut tubers at 14DAP

The use of cotton wool resulted in a higher number of sprouted tubers across all experimental days. Lower number of sprouted tubers in polythene bags when soaking was beyond 24 hours could mean that tubers soaked beyond 24 hours already had imbibed water to their maximum capacity, bringing them into a condition of saturation with moisture, and relatively higher temperature could have led to injury and probably death of some tubers.

\subsection{Interactions of priming hours and tuber sizes on sprouting of tiger nut}

Figure 12 shows the interaction between priming duration and tuber sizes on the sprouting of tiger nut tubers. Both large and medium sized tubers produced significantly $(p<0.05)$ higher number of sprouts at 48 hours of soaking. On the other hand, small sized tubers could not tolerate soaking beyond 24 hours; thus for small sized tubers, maximum number of sprouted tubers were obtained at 24 hours of soaking which was similar to the control. Beyond 24 hours of soaking the 
number of sprouted tubers continuously and significantly declined for small sized tubers. construct, with the hptII gene (Figure 1 - only 20 out of 139 regenerants are presented, Table 4).

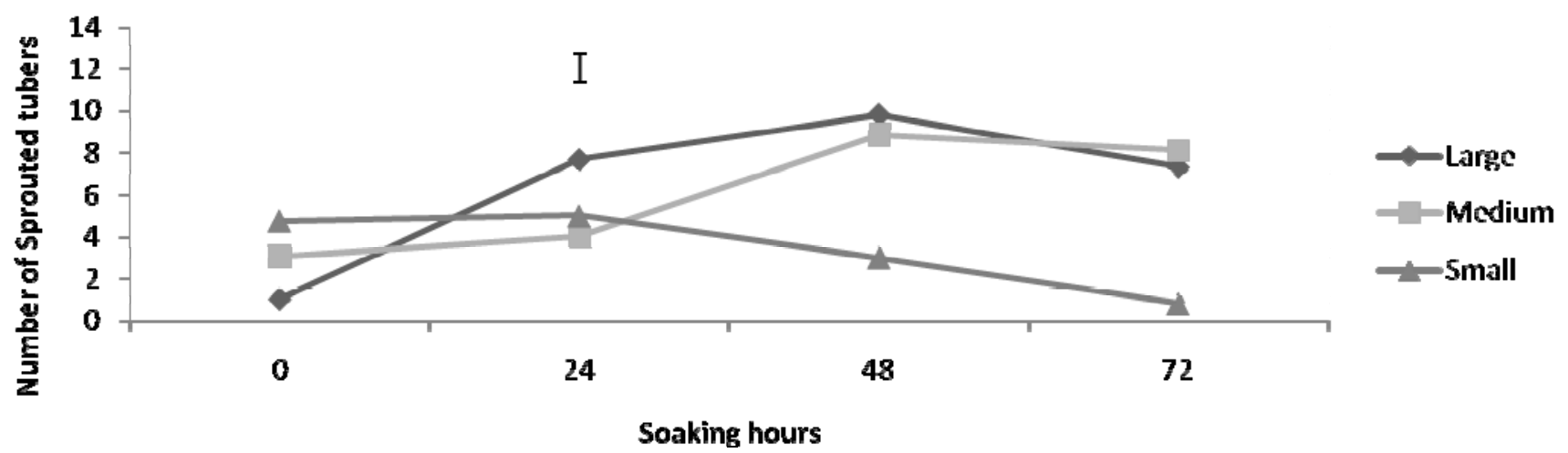

Figure 12: Interaction of soaking hours and tuber sizes on sprouting of tiger nut tubers at 3DAP

The results obtained in this trial in which interactions between tuber sizes and soaking hours significantly affected rate and total number of sprouted tubers can be attributed directly to variations in the mass of the tubers; even though imbibitions could have been at similar rate, saturation was faster in the small sized tubers relative to the medium and large tubers. Keeping small sized tubers beyond 24 hours in water would have made some of the tubers to be water-soaked and died. This finding is very crucial as tubers are seldom sorted before soaking; Teiteh and Ofori (1998) reported that in Ghana the common practice among local growers of tiger nut is to soak the tubers in water for 3 to 4 days to facilitate germination. This finding therefore suggests that tubers should be sorted and soaked for different hours based on their sizes before planting.

\subsection{Effects of tuber sizes and soaking hours and growth media on temperature of the growth media during sprouting of tiger nut tubers}

Tuber sizes and soaking duration had no significant effect on the temperature recorded in the sprouting tiger nuts, however the temperature recorded in the growth media differed significantly (Table 2). Higher significant temperatures were recorded in the polythene bags across the period of observation except at the $5^{\text {th }}$ and $11^{\text {th }}$ day. There were no significant differences in all the interactions. 
Table 2: Effects of tuber sizes and soaking hours on temperature of growth media during sprouting of tiger nut tubers

\begin{tabular}{|c|c|c|c|c|c|c|c|c|c|c|c|c|}
\hline \multicolumn{13}{|c|}{ Temperature $\left({ }^{\circ} \mathrm{C}\right)$ of growth media at different days after planting } \\
\hline & $3^{\text {rd }}$ & $4^{\text {th }}$ & $5^{\text {th }}$ & $6^{\text {th }}$ & $7^{\text {th }}$ & 8th & $9^{\text {th }}$ & 10th & 11th & 12th & 13th & $14^{\text {th }}$ \\
\hline \multicolumn{13}{|l|}{ Tuber Size } \\
\hline Small & 33.8 & 33.4 & 33.0 & 32.9 & 32.4 & 33.5 & 33.5 & 35.1 & 33.0 & 33.3 & 33.0 & 35.4 \\
\hline Medium & 34.0 & 33.5 & 33.0 & 33.0 & 32.5 & 33.8 & 33.5 & 35.4 & 33.0 & 33.5 & 34.0 & 35.5 \\
\hline Large & 34.0 & 33.5 & 33.0 & 33.0 & 32.5 & 33.7 & 33.5 & 35.3 & 33.0 & 33.5 & 34.0 & 35.5 \\
\hline LSD & ns & ns & ns & ns & ns & ns & ns & ns & ns & ns & ns & ns \\
\hline \multicolumn{13}{|c|}{ Soaking hours } \\
\hline $\mathbf{0}$ & 33.8 & 33.2 & 33.0 & 32.9 & 32.3 & 33.4 & 33.4 & 35.2 & 33.0 & 33.2 & 33.9 & 35.3 \\
\hline 24 & 34.0 & 33.7 & 33.0 & 33.0 & 32.5 & 33.8 & 33.6 & 35.3 & 33.0 & 33.5 & 34.0 & 35.5 \\
\hline 48 & 34.0 & 33.4 & 33.1 & 33.0 & 32.5 & 33.8 & 33.5 & 35.1 & 33.0 & 33.5 & 34.0 & 35.5 \\
\hline 72 & 34.0 & 33.5 & 33.0 & 33.0 & 32.5 & 33.7 & 33.5 & 35.3 & 33.0 & 33.5 & 34.0 & 35.5 \\
\hline LSD & ns & ns & ns & ns & ns & ns & ns & ns & ns & ns & ns & ns \\
\hline \multicolumn{13}{|c|}{ Growth Media } \\
\hline Cotton Wool & 32.0 & 31.0 & 33.1 & 32.0 & 31.0 & 32.1 & 33.0 & 34.0 & 33.0 & 31.0 & 33.0 & 34.0 \\
\hline Poly Bag & 35.9 & 35.9 & 33.0 & 33.9 & 33.9 & 35.3 & 34.0 & 36.5 & 33.0 & 35.9 & 34.9 & 36.9 \\
\hline LSD & 0.22 & 0.28 & ns & 0.11 & 0.17 & 0.23 & 0.08 & 0.2 & ns & 0.28 & 0.11 & 0.08 \\
\hline $\mathbf{T S} \times \mathbf{S H}$ & ns & ns & ns & ns & ns & ns & ns & ns & ns & ns & ns & ns \\
\hline $\mathbf{T S} \times \mathbf{G M}$ & ns & ns & ns & ns & ns & ns & ns & ns & ns & ns & ns & ns \\
\hline $\mathbf{G M} \times \mathbf{S H}$ & ns & ns & ns & ns & ns & ns & ns & ns & ns & ns & ns & ns \\
\hline $\mathbf{T S} \times \mathbf{S H} \times \mathbf{G M}$ & ns & ns & ns & ns & ns & ns & ns & ns & ns & ns & $\mathrm{ns}$ & $\mathrm{ns}$ \\
\hline
\end{tabular}

TS - Tuber Sizes $\quad$ SH - Soaking Hours $\quad$ GM - Growth Media ns= not significant

Higher significant temperatures obtained in the polythene bag in this study can be attributed partly to the color of the material as black body tend to absorb more heat, and the heat could easily be trapped in the polythene bags relative to the cotton wool, dark colors also absorb heat more effectively than light colors (www.calwineries.com/learn/grapegrowing/terrain/heat-retention). Black body absorbs all radiation incidents on its surface and they appear black because of complete absorption of all wavelengths (Bowden and Honsberg, 2015). Variation in temperature of the growth media could also have contributed to the variation observed in the rate of sprouting between the two media. Germination, speed of germination and average germination time were positively influence when seeds of Diptychandra unrantiaca (Mart.) Tul., were grown at the temperature of $25{ }^{0} \mathrm{C}$ to $30{ }^{\circ} \mathrm{C}$ (Morbeck de Oliveira et al., 2013). The effect of the black body was aggravated because of poor circulation of air in the polythene bags. This implies that even though there was restriction of oxygen during soaking, ample aeration should be allowed when the tubers are being sprouted. Since aeration could be a major militating factor in polythene bags, perforation of the bags could be tried to enhance aeration. Confirmation of this can be made in future studies by measuring the oxygen content in both growth media. 


\section{CONCLUSIONS}

The results of the present study have shown that in tiger nut, cotton wool provided a better sprouting medium than polythene bag. Priming for 48 hours could be adequate when sprouting was done on cotton wool. Large and medium sized tubers, as used in this study, could tolerate up to 48 hours of soaking while soaking small tubers beyond 24 hours led to a reduction in number of sprouted tubers. Therefore, it can be concluded that in tiger nut production, the soaking duration can have a significant effect on the sprouting of the tubers.
Smaller tubers require shorter period of soaking in order to achieve good sprouting, and cotton wool is a better sprouting medium relative to polythene bags. Sorting of tubers meant for planting is therefore recommended in tiger nut production and if sorting is not possible, soaking should not exceed 24 hours. The medium sized tubers are probably the most desirable as planting material. Cotton wool or cotton material could be considered the best sprouting medium.

\section{REFERENCES}

Bamishaiye, E.I. and Bamishaiye O.M. 2011. Tiger nut: As a plant, its derivatives and benefits. African Journal of Food, Agriculture, Nutrition and Development. 11(5):5157-5170. DOI: 10.4314/ajfand.v11i5.70443

Bowden, S. and Honsberg, C. Blackbody Radiation http://www.pveducation.org/pvcdrom/propertiesof-sunlight/blackbody-radiation Accessed $14 / 12 / 2015$

Bradford, K. J., Côme, D. and Corbineau, F. (2007). Quantifying the oxygen sensitivity of seed germination using a population-based threshold model Seed Science Research 17: 33-43. DOI: $10.1017 /$ S0960258507657389

Cyperus esculentus: https://en.wikipedia.org/wiki/Cyperus_esculentus Accessed 14/12/2015

Heat retention in vine yard soils www.calwineries.com/learn/grapegrowing/terrain/heat-retention Accessed $14 / 12 / 2015$

Hillocks, R. J. (1998). The potential benefits of weeds with reference to small holder agriculture in Africa. Integrated Pest Management Reviews 3(3): 155 167. DOI: $10.1023 / \mathrm{A}: 1009698717015$

Imam, T.S., Aliyu, F.G. and Umar, H.F. (2013). Preliminary phytochemical screening, elemental and proximate composition of two varieties of Cyperus esculentus (tiger nut). Nigerian Journal of Basic and Applied Science, 21(4): 247-251). DOI: 10.4314/njbas.v21i4.1
Morbeck de Oliveira, A. K., Ribeiro, J.W.F., Pereira, K. C. L. and Silva, C. A. A. (2013). Effects of temperature on the germination of Diptychandra aurantiaca (Fabaceae) seeds. Acta Scientiarum Agronomy. 35(2):203-208.

National Centre for Genetic Resources and Biotechnology (NACGRAB). (2008). Country report on the state of plant genetic resources for food and agriculture, 50 pages.

Power, J. P., and Fonteyn P. J. (1995). Effects of oxygen concentration and substrate on seed germination and seedling growth of Zizania texana (Texas wildrice). Southwestern Naturalist, 40: 1-4

Sánchez-Zapata, E; Fernández-López, J; Angel PérezAlvarez, J (2012). "Tiger nut (Cyperus esculentus) Commercialization: health aspects, composition, properties, and food applications". Comprehensive Reviews in Food Science and Food Safety, 11: 366-77. DOI: 10.1111/j.1541-4337.2012.00190.x

Teiteh J.P. and Ofori E. (1998). A baseline survey of tiger nut (Cyperus esculentus) production in the KwahuSoqth District of Ghana. Ghana Journal of Agricultural Science, 31:211-216.

Tiger nuts http://www.tigernuts.com/tigernuts-health/ Accessed 14/12/2015

Top 10 health benefits of tiger nuts. www.naij.com. $>$ Health and beauty accessed 14/12/2015 